\title{
ImPlications of A NuClear Iran for Turkey
}

\section{Mustafa Kibaroglu and Baris Caglar}

\author{
Dr. Kibaroglu teaches courses on arms control and disarmament in the \\ Department of International Relations at Bilkent University in Ankara. Mr. \\ Caglar is a doctoral student and research assistant in that department.
}

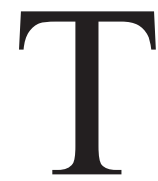

urkey is a country that will be most negatively affected by Iran's nuclear-weapons capability, if and when it is developed.

If Iran builds a nuclear stockpile, it will only add a new dimension to its already militarily superior position vis-à-vis the Gulf states: the United Arab Emirates, Qatar and Saudi Arabia, in particular. Syria will most likely remain Iran's one and only ally in the region, primarily due to geopolitical considerations, at least for as long as the Asad dynasty or a like-minded ruler remains in power.

Relations between Iran and the former Soviet republics in the Caucasus and Central Asia have grown steadily in many areas since they gained their independence. No serious bone of contention exists between them and Iran, with the exception of the Azeri people's aspirations to "greater Azerbaijan" on both sides of the Iranian-Azerbaijani border. ${ }^{1}$ However, these calls are not powerful enough to trigger a secessionist movement in the region if Iran, with its Azeri clerical leader Ali Khamenei, develops nuclear weapons. Russia, the second-largest nuclear power in the world, will not be challenged, even if
Iran builds a small stockpile of nuclear weapons. Aside from the huge imbalances between the two countries, no major hostilities are on the horizon. There is also a patron-client relationship between the two, especially in the nuclear field, that is likely to continue to strengthen Russia's hand.

Iran's would-be nuclear-weapons capability is not going to pose a serious challenge to Pakistan, India or China, either. All three are nuclear powers already, and none of them have an adversarial relationship with Iran that would lead to a confrontation in the foreseeable future. On the contrary, China and India's dependency on Iran's oil and gas supplies is likely to increase, affecting the pace of their bilateral relations in favor of Iran. ${ }^{2}$

On the other hand, the hostile relationship between Iran and the United States is likely to persist in the coming years, as long as Iran insists, inter alia, on continuing its nuclear program. ${ }^{3}$ However, the presence of a handful of nuclear weapons in Iran's military arsenal will not alter its inferior position to the United States for a long time to come. Similarly, Israel's nuclear capability will remain, by all measures, a credible deterrent against nuclear blackmail 
by Iran. Moreover, in the Middle Eastern context, the Israeli nuclear capability cannot be considered separately from that of the United States. As such, Iran would not gain the upper hand in its relations with Israel just because it had nuclear weapons. By the same token, Iraq, where the United States is building a new nation as its protectorate, will most likely be given strong, positive security guarantees with a long-term commitment that will serve as a credible deterrent against Iran's would-be nuclear-weapons capability.

Regarding Turkey, however, the presence of nuclear weapons in the Iranian military arsenal will upset the delicate balance that has existed between the two nations since the Treaty of Kasr-i Shirin in 1639, in favor of Iran. ${ }^{4}$ The topographic and demographic characteristics of the region and the presence of more or less equal military capabilities on both sides of the border have since forced the parties to refrain from confronting each other. Turkish authorities, both civilian and military, would be expected to have raised much more serious concerns about Iran's efforts to become a nuclear power, especially following the revelations in August 2002 by an Iranian opposition group of Iran's secret uranium-enrichment and heavy-water production facilities, which are clear indications of Iran's long-term ambitions. ${ }^{5}$ Nevertheless, Turkey has been reluctant to assume a higher profile about this matter; this would probably not have been the case until only a few years ago.

\section{TURKEY'S RELUCTANCE TO CHALLENGE IRAN}

Until the Islamic revolution in Iran in 1979, the Turks and the Iranians had relatively quiet and harmonious relations for more than three centuries without even a serious border dispute. Yet the ambition of the clerical leadership in Iran to export its fundamentalist principles to secular and democratic Turkey caused serious tension, as the secular Republic of Turkey was created in 1923 out of the ashes of the Ottoman Empire, where Islamic sharia law was applicable to the Muslim population. The perpetuation of secular principles by the predominantly Muslim Turkish population has since been a highly sensitive issue in domestic politics.

In the early 1990s, Turkey's secular elite blamed Iran for supporting religious extremist groups in Turkey. They also held Iran responsible for a series of assassinations that claimed the lives of a number of prominent secular intellectuals who had pointed out the dangers of the Iranian mullahs' designs on Turkey. ${ }^{6}$ Moreover, Turkish security officials have on a number of occasions provided evidence of Iran's logistical support to PKK terrorists who found refuge on the Iranian side of the border. Added to these strains was the competition between Turkey and Iran over the "leadership" of the former Soviet republics in the Caucasus and Central Asia, which had cultural and religious common denominators with both Turkey and Iran. ${ }^{?}$

As a result of the events leading up to the U.S. invasion of Iraq in 2003, however, the relationship between Turkey and Iran has entered a new phase. Similar concerns about the probable consequences of developments in Iraq may have motivated the two countries to merge their political stances with respect to regional political issues. Since then, there has been an unprecedented rapprochement between Turkey and Iran resulting in an increase in high-level official visits. 
Despite these positive signs, it is still too early to say that relations between Turkey and Iran will stay on the same track for the long term. The nature as well as the extent of Iran's nuclear program is highly likely to have a decisive impact on the future of Turkish-Iranian relations. However, there are too many unknown factors that require further cooperation between Iran and the international community and its neighbors in order to provide more transparency about its nuclear program.

\section{IRAN'S CHANGING IMAGE IN TURKEY}

Less than a decade ago, had Iran displayed similar ambitions to develop elaborate nuclear capabilities, it would have been confronted with much more negative reactions from Turkey's public and government. A decade ago, the political climate in Turkey was dramatically different, the actors in the decision-making posts were entirely different, and Turkey's relations with its neighbors were on a substantially different track.

Back in the 1990s, Iran's image in Turkey was of a "dark" regime trying to cause instability in Turkey and pave the way to a similar (Islamic) revolutionary movement. The tension has heightened with the participation of the Iranian ambassador to Ankara in a so-called "Jerusalem night" organized by the Mayor of Sincan, Bekir Yildiz, in a middle-sized suburb, heavily populated with "religious" people. ${ }^{8}$ It was reported that the Iranian ambassador delivered fundamentalist messages to the audience, harshly criticized Turkey's secularism, and cursed Mustafa Kemal Ataturk, founder of the republic, for his secular principles following the War of Liberation (1919-22).
Shortly after this incident, on February 4 , 1997, a convoy of main battle tanks and armored vehicles rolled through the streets of Sincan. ${ }^{9}$ The purpose was said to be to display the determination of the secular circles in the country, the armed forces at the forefront, to defend the secular characteristics of the government. This event was also said to be responsible for sparking a series of developments and popular demonstrations that put an end to the two-party Refah-Yol government in June of that year. ${ }^{10}$

The Refah-Yol government was formed by the Welfare party (Refah Partisi, RP), whose leader, Necmettin Erbakan, was the prime minister, and by the True Path party (Dogru Yol Partisi, DYP) from the center-right, conservative wing, whose leader, Tansu Ciller, was the deputy prime minister. The Refah-Yol government was the result of the democratic elections in spring 1996. Half a dozen parties entering the Grand National Assembly had difficulty forming a coalition without the RP deputies, seen at the time as the representatives of the Islamist factions in Turkey.

During his long career in politics, Erbakan was well known for his Islamist approach to politics. The Constitutional Court in the 1970s and the military coup leaders in the 1980s shut down his parties, the National Order party (Milli Nizam Partisi, MNP) and the National Salvation party (Milli Selamet Partisi, MSP). Yet, as long as Erbakan was perceived as representing only a small percentage of the Turkish population that hoped to institute sharia law, he did not pose an imminent threat to the regime. However, his unpredicted rise to the premiership and hasty attempts to shift the direction of Turkey's mainstream foreign-policy 
orientation from the West to the Islamic world were not acceptable to the "guardians of the regime" (the army). His decision to pay his first official visit as the prime minister of Turkey to the Islamic Republic of Iran and his second visit to Colonel Qaddafi's Libya generated much reaction in Turkey's mainstream secular circles. Such visits were out of the ordinary in the history of the Turkish Republic. He was, therefore, driven out of office after only about a year, in a so-called postmodern coup. ${ }^{11}$ The Constitutional Court eventually shut down his Welfare party ${ }^{12}$ in January 1998 and its successor, the Virtue party (Fazilet Partisi, FP), in June $2001^{13}$ on the grounds that they "became the logistical headquarters of the attempts of the Islamist factions in Turkey to overthrow the secular democratic regime that was founded on Ataturk's principles."

\section{IMPROVED IMAGE}

The Sincan incident alone shows how closely Iran's activities in Turkey were being monitored and how promptly state structure confronted them. Nevertheless, today there is a substantially different attitude toward Iran, even though its nuclear-weapons capability, if developed, is likely to pose a much more serious threat to the secular democratic regime in Turkey. There must be an explanation for such a change of attitude. Revelations about Iran's large-scale clandestine nuclear activities came at a time when dramatic changes had taken place both in Turkey and the world, changes that resulted in the apparent reluctance of Turkey to challenge Iran on the nuclear issue.

Until September 11, 2001, Turkey's relations with the United States were quite good. There were only sporadic disagree- ments, albeit serious ones, over the enforcement of the no-fly-zone policy toward Iraq that had been in place since 1991. According to many in Turkey, this policy helped an autonomous Kurdish political entity in northern Iraq to flourish. ${ }^{14}$ Relations with Israel, on the other hand, were historically very good, reaching their zenith with the signing of a comprehensive military agreement in 1996 that encompassed the upgrading by Israel of Turkey's aging air power. ${ }^{15}$ The role of Israel in Turkey's unprecedented pressure on Syria in autumn 1998 to cease its longstanding support of the PKK terrorist organization as well as to expel its leader, Abdullah Ocalan, from Syria (later captured in Kenya), cannot be underestimated.

Notwithstanding the generally good relations between Turkey and the United States and Israel, a series of developments took place in the aftermath of the September 11 attacks that have dramatically altered the vision of the world on both sides. According to many political analysts and statesmen alike, Turkish-American relations suffered an unprecedented blow with the failure of a resolution in the Turkish Grand National Assembly on March 1, 2003, that would have allowed the deployment of tens of thousands of U.S. troops in Turkish territory as part of the war against Iraq. ${ }^{16}$

Another serious blow to bilateral relations came on July 4, 2003, when U.S. troops detained a dozen soldiers from the Turkish Special Forces who had been operating for more than a decade in the northern districts of Iraq, monitoring and collecting intelligence with the knowledge of U.S. authorities. This shocking incident, which appalled Turkish military authorities as well as the entire nation, has since been 
the source of the skyrocketing antiAmerican feelings in almost every segment of Turkish society.

Moreover, the obvious support by the United States of Kurdish groups in northern Iraq, who are believed by many in Turkey to be only a few steps away from proclaiming independence, also damaged bilateral relations. Added to these is the belief that the United States is preventing Turkey from launching a military operation against the Kandil Mountains on the Iranian border in northern Iraq, which are used by thousands of PKK terrorists as a safe-haven from which to attack Turkish security forces and villagers in Turkey.

Israel is believed in Turkey to be closely linked with those U.S. policies toward Iraq in general and the Kurdish region in particular that ultimately hurt Turkey's vital interests in the region. ${ }^{17}$ Some analysts in Turkey go even further, asserting that Israel actually dictates these policies to the United States, thanks to its influence on Capitol Hill. ${ }^{18}$

Apart from such mainly nationalist (ulusalci) interpretations of U.S. and Israeli policies toward the Middle East in general and Iraq in particular, there is also a separate Islamist interpretation of what is happening in and around Turkey and why. ${ }^{19}$ The reactions of the Christian and Jewish populations to the September 11 attacks have resulted in anti-Islamic rhetoric from many Western politicians and media. In most cases, Islam is directly or indirectly associated with terrorism; or, at best, religious extremism is an antagonist to Western culture, the "other." Such an approach has resulted in counterreactions in the Islamic world that triggered brutal demonstrations in Muslim countries against Christianity and Judaism and their repre- sentatives. The military offensives of U.S. troops in Iraq that were covered extensively in the Muslim media have also deeply affected public opinion and fueled anti-Americanism.

Hence, the coming of the Justice and Development party (Adalet ve Kalkinma Partisi, AKP) to power in Turkey with an Islamist as well as a liberal-conservative appeal in the November 2002 general elections cannot be fully explained without considering the background mentioned above. ${ }^{20}$ The foreign-policy behavior of the AKP toward the United States and Israel has been generally in conformity with Turkey's traditional approach. Yet many in Turkey saw the AKP as a continuation of the Islamist parties - the MSP, the RP and the FP, all of which were banned from politics - and Recep Tayyip Erdogan, the leader of the AKP and the prime minister, as being no different than Erbakan. At first, the AKP government did not choose to confront the United States and Israel head-on regarding foreign-policy matters.

However, deputies of the AKP and Prime Minister Erdogan himself eventually started to make bitter statements about Israel and its policies toward the Palestinians, in particular. Prime Minister Erdogan has publicly criticized Israel, here and there, for "committing state terror" following the planned assassinations of the spiritual leaders of Hamas and the demolition of Palestinians' houses in Gaza by the Israeli security forces. Moreover, despite the fact that Hamas was officially recognized as a terrorist organization by Turkish authorities, the Hamas leader-in-exile, Khaled Meshal, was given a warm reception in the AKP headquarters in Ankara in February 2005. ${ }^{21}$ 
These and other developments have apparently distanced Turkey from Israel. Although statements were made to the contrary after official visits - fewer in number and at lower levels than those of only a few years ago and with much less warmth before the cameras - relations are still far from the levels they could have reached with the momentum that was built less than a decade ago. ${ }^{22}$

The nationalists in Turkey applaud the Iranian leadership and their "dignified" policies for protecting Iran's rights and national interests against the world's "only superpower." They also suggest a similar attitude to the Turkish politicians, whom they harshly criticized for their inability to take measures, under pressure from the U.S. administration, against Kurdish leaders or the PKK terrorists in northern Iraq. The Islamists, on the other hand, support Iran's quest for nuclear power, which, in their view, terrifies Israel and will bring the Jewish state to respect their Muslim brothers in Palestine and elsewhere in the world.

Against this background, it is not difficult to understand public sentiment in Turkey toward the United States and Israel. Negative feelings toward these countries, which were Turkey's closest allies in the recent past, have not only resulted in the gradual worsening of bilateral relations at the governmental level, but also have caused the Turks to lend huge support to other countries, such as Iran, that defy U.S. and Israeli policies.

\section{IRAN'S NUCLEAR AMBITIONS}

There is little wonder that public sentiment toward other nations affects the foreign policies of governments every- where in the world. AKP governments, since 2002, have proved not to be exceptions to this rule; they are reluctant to challenge Iran on the nuclear issue due to the support among the Turkish public for Iran's nuclear program. However, governments have a primary duty to pursue the vital interests of their nations. This requires, among other things, avoiding emotional approaches to the formulation of foreign and security policies. Therefore, Turkey, even under the current AKP government, may be forced to change its reluctant attitude, if and when Iran advances its nuclear capabilities and gets closer to the threshold of nuclear-weapons manufacturing. Moreover, Turkey has been elected to the UN Security Council as a non-permanent member and also to the Board of Governors of the International Atomic Energy Agency (IAEA) for the next couple of years. It is highly likely that Iran and its nuclear program will figure heavily on the agendas of both organizations. Turkey will have to vote one way or another on these matters and may make significant constructive contributions in the eventual peaceful resolution of the dispute between Iran and the West.

\section{TURKEY'S POSITION ON IRAN'S NUCLEAR PROGRAM}

Turkey officially recognizes the right of Iran, a member of the Treaty on the NonProliferation of Nuclear Weapons (NPT), to develop nuclear technology, provided that it remains on a peaceful track and allows for the application of full-scope safeguard inspections by the IAEA in a way that would lend the utmost confidence to the international community about its intentions. Prime Minister Erdogan has made statements to this effect on a number 
of occasions. In an interview with the Kuwaiti newspaper El Anba in March 2007, he reiterated the diplomatic position of his government: "States have the right to possess nuclear energy to utilize for peaceful purposes." He also emphasized that Turkey has good neighborly relations with Iran and that the two countries have developed mechanisms for the purpose of cooperation on security issues. ${ }^{23}$

More recently, at the Munich Security Conference in February 2008, Prime Minister Erdogan responded to a journalist's question as to "why Turkey did not seem to be worried" about Iran's nuclear program: "Our Iranian colleagues tell us that they want nuclear energy for peaceful purposes to satisfy their energy needs, not for weapons." Erdogan reiterated that the work in the nuclear field would soon start in Turkey: 'I'm afraid some people may accuse us of having ambitions for producing weapons of mass destruction, too." 24

In addition to the pressure emanating from the warm attitude of the Turkish people toward Iran on the nuclear issue, especially among the constituents of the AKP government - partly because Turkey will soon launch yet another bid to establish its first nuclear reactor, and partly due to the fact that no clear violations of Iran's NPT obligations have been reported — Turkey's official position regarding Iran's nuclear program has been lowprofile, at least for the time being.

However, consensus among the Turkish political and security elite is that, contrary to its official stance, Turkey cannot stay aloof from Iran's nuclearization for long, even under the AKP government. ${ }^{25}$ If and when unequivocal signs of Iran's efforts to advance its existing nuclear capability toward weaponization are received by Turkish authorities through various sources, it is highly likely that the issue will figure more frequently on the National Security Council's agenda. ${ }^{26}$ There have already been statements from leading figures in Turkey expressing concern about Iran's nuclear program and its intentions.

In an address to the Turkish War Colleges in Istanbul in April 2005, then Chief of the Turkish General Staff Gen. Hilmi Ozkok stated, "Doubts about Iranian efforts to influence the regimes of the surrounding states have disturbed Turkey and have been responsible for the low level of relations between Turkey and Iran." After asserting that Turkey, like other states, had observed Iran's nuclear efforts with concern, Gen. Ozkok said, "Creation of a Nuclear Weapons Free Zone in the Middle East is Turkey's policy."27

Similarly, then Minister of Foreign Affairs Abdullah Gul (currently the president of the Turkish Republic), in response to a motion in the Turkish Grand National Assembly in June 2006, stated, "The IAEA Director General's reports have revealed the fact that Iran concealed its nuclear program for years, which creates suspicions about Iran's intentions." After mentioning that Ankara was carefully observing developments in the Iranian nuclear program, which had gradually attained a more serious dimension, Gul said, "The emergence of the possibility of Iran's possessing a nuclear weapon disturbs Turkey, as all the members of international society." 28

On the same subject, speaking at the World Economic Forum in May 2006, Prime Minister Erdogan emphasized the facilitating role of political dialogue and 
political approaches to the settlement of the Iranian issue. Turkey, he said, "ought to take certain steps as a neighbor of Iran, but it is impossible for Turkey to approach the nuclear energy issue when it is perceived as weapons of mass destruction." ${ }^{29}$

\section{INSTITUTIONAL LIABILITIES}

Notwithstanding the current apparent reluctance of Turkey to challenge Iran, which is due partly to the lack of a coherent approach toward Iran in the international arena, the above statements suggest that Turkey is indeed carefully monitoring the situation from a wider perspective. At the same time, Ankara is determining alternative policies to minimize the possible negative effects to its national interests and security of the eventual weaponization of Iran's nuclear program. Nevertheless, Turkey does not have a wide array of choices due to a number of limitations arising from its institutional liabilities.

\section{Membership in Non-Proliferation Regimes}

In a broader context, the fundamental thrust of Turkish foreign and security policy has been for Turkey to become a state party to international arms control and disarmament agreements, wherever appropriate, so as to contribute to their effective implementation. Accordingly, Turkey became a state party to the NPT by signing the treaty on January 28, 1969, and subsequently ratifying it on April 17, $1980 .^{30}$ It also became a state party to the Biological Weapons Convention of 1972 (ratifying it in November 1974) and signing the Chemical Weapons Convention of 1993 (ratifying it in April 1997). Moreover, Turkey took steps in the late 1990s to become a member of the Nuclear Suppli- ers Group (NSG) and was successful in June 2000. ${ }^{31}$ Turkey has sped up the process of adjusting its national exportcontrol regime (laws and regulations) to that of the NSG countries. Turkey has undertaken the same stance toward the Zangger Committee and became a member, almost as an automatic outcome of its formal accession to the NSG. ${ }^{32}$

In April 1997, Turkey also became a member of the Missile Technology Control Regime (MTCR), which aims to demonstrate to the actual and potential proliferants that there is a solid bloc of likeminded nations that are unified in the determination to fight against proliferation. ${ }^{33}$ Because of the two small nuclear research reactors operating in the country, Turkey signed the Comprehensive Test Ban Treaty (CTBT) in 1996 and ratified it in 2000 as one of 44 states whose ratification was necessary for the treaty to become effective. ${ }^{34}$ As a member of the Conference on Disarmament (CD), Turkey is "pleasured" to have joined the overwhelming majority of nations in the effort to conclude the CTBT. The complete ban on nuclear testing, the core function of the treaty, is thought by Turkish officials to be an effective measure to control nuclearweapons technology and an important step toward the eventual elimination of nuclear weapons.

As a country that never sought to acquire weapons of mass destruction, Turkey also contributed to international efforts to strengthen the NPT regime and participated actively in the process of enhancing the IAEA's verification system with a view to making safeguard inspections more intrusive. As for the Additional Protocol that was released by the IAEA as a result of "Programme 93+2," Turkey 
became a state party to it by signing and ratifying the document in July $2000 .^{35}$

Against this background, one might argue that Turkey's record in the nuclear field has been one of success in its nonproliferation standing, but an undisputed failure in exploiting the peaceful applications of nuclear technology. ${ }^{36}$

\section{NATO Membership}

The second reason for limited options vis-à-vis the rise of a nuclear-weaponscapable Iran is Turkey's membership in the North Atlantic Treaty Organization (NATO). As a member of NATO since 1952, Turkey is theoretically given "positive security guarantees" by the other members of the alliance, according to Article 5 of the 1949 Washington treaty, meaning that Turkish territory would be covered by a "nuclear umbrella" against attacks from other countries, including Iran. Turkey has accepted deployment of U.S.-origin nuclear weapons on its soil in accordance with the nuclear strategies of the alliance since the decision taken at the 1959 NATO summit in Rome. ${ }^{37}$ The presence of U.S. nuclear weapons in Turkey may be considered by outside observers and by experts inside Turkey to be an insurance policy that would be sufficient to deter possible intentions of Iran in the future. ${ }^{38}$

\section{EU Candidacy}

A third reason that limits the options available to Turkish decisionmakers in case Iran has weaponized its nuclear infrastructure is Turkey's candidate status before the European Union (EU). As such, if developed, Turkey's nuclear program would be under the scrutiny of the relevant institutions of the EU throughout the accession negotiations. If and when the accession process is successfully completed, Turkey will have to become a state party to the EURATOM Treaty as a condition of full membership. This would permit only peaceful applications of nuclear technology.

\section{DEFICIENCIES OF INSTITUTIONS LIMITING TURKEY'S OPTIONS}

All three reasons mentioned above suggest that Turkey will not follow the path of Iran by developing a dubious nuclear infrastructure that may have weapons implications in the future. However, will the current standing of Turkey remain the same for a long time to come? It is difficult to give an affirmative answer to this question with great confidence, due to changing circumstances both inside and outside of Turkey. Relations with the above-mentioned institutions, which are presented as insurance policies against Turkey's potential inclination toward "going nuclear," may not remain on the same track in the long term.

\section{Weakening of the NPT Regime}

Regarding the danger of the spread of WMD in the world, Turkey's fundamental policy has long been to support international initiatives that aim at strengthening the chemical, biological and nuclear nonproliferation regimes, with special emphasis on their inspection and verification mechanisms. However, a series of developments over the last decade has cast doubts on the future prospects of the NPT regime: North Korea's nuclear detonation; revelations about Iran's secret facilities suitable for fissilematerial production; the U.S.-India nuclear deal; failure to get the ratification of the IAEAAdditional Protocol from all concerned states, including Iran; failure to urge the enforcement of the Comprehensive Test-Ban 
Treaty (CTBT); and failure to start negotiations for a Fissile Material Cut-Off Treaty (FMCT). This list could be expanded.

Added to these has been the unequal and unacceptable treatment of Turkey by the major Western suppliers of nuclear technology, such as the United States, Germany and Canada, resulting in the failure to install nuclear power plants in the country. ${ }^{39}$ This situation caused a loss of confidence among the Turks in the value of the "bargain" inherent in the NPT: in return for denouncing nuclear weapons, member states would benefit from nuclear technology transfer from other countries and/or develop as much as they needed indigenously under international safeguards.

Turkey has acted as a responsible member of the nuclear-non-proliferation community and will remain so for the foreseeable future. Therefore, it is not easy to argue with great confidence that the next generations of Turkish decisionmakers will display similar unequivocal loyalty to the nuclear non-proliferation regime, if Iran, under the NPT provisions, cannot be prevented from manufacturing nuclear weapons or from developing breakout capabilities that may enable it to assemble weapons in a short period of time. ${ }^{40}$

\section{Disputed NATO Security Guarantees}

Membership in NATO has meant more than security guarantees for most Turks. NATO has been perceived as part of Turkey's "Western" identity. Throughout the Cold War years, Turkey entertained an undisputed status as a staunch ally of the West. However, the collapse of the Warsaw Pact and the disintegration of the Soviet Union brought down its reputation as an indispensible ally and a bulwark against the Communist threat. Soon after, the alliance failed the first immediate test of solidarity with Turkey, when Turkish President Turgut Ozal called upon NATO in 1991 to deploy the Rapid Reaction Force in Turkey against the threat posed by Saddam Hussein's Iraq following its invasion of Kuwait in August 1990. The Western European members of NATO, in particular, have dragged their feet in living up to their Article 5 commitments, arguing that the Middle East was "out of the area" of NATO's operation zone. ${ }^{41}$

A similar situation arose in 2003, when Turkey formally asked the North Atlantic Council to activate Article 4 of the Washington treaty with a view to starting deliberations on the possible measures that each member nation would have to take in the run-up to the second Gulf War, in order to protect Turkey against Iraq's missiles and WMD. NATO members once again failed to honor their treaty obligations toward Turkey. Added to these, the process of the transformation of the alliance from a collective-defense organization with a "hard power" stance to a collectivesecurity organization with a perceived "soft power" attitude, has further diluted the image of NATO in the eyes of most Turks.

No less important is the effect of antiAmerican sentiments among the Turkish public in undermining the significance of NATO, which is starting to be seen as serving primarily the interests of the United States and helping it to establish its world hegemony. ${ }^{42}$ A number of remarks have already been made publicly by high-ranking military officers, civilian bureaucrats and politicians suggesting that Turkey withdraw from NATO and intensify relations with other regional organizations instead. ${ }^{43}$ Although immature at this stage, the antiNATO attitude may grow to a significant 
level, as long as the alliance remains indifferent to Turkey's fight against the PKK, some of whose members have long found refuge in the territories of the allied countries. Top military commanders, diplomats and politicians in Turkey have, time and again, emphasized the need for the alliance to display its solidarity with Turkey in its fight against terrorism. The lack of such solidarity only exacerbates the frustration of the Turkish public. ${ }^{44}$

\section{EU Reluctance}

Turkey has been striving to be a part of the European integration process for nearly half a century. Turkey and the European Economic Community (EEC) signed the Ankara Treaty in 1963, giving Turkey, in theory, a full-membership perspective. However, only after a long period of ups and downs did Turkey manage to get a date in 2004 to start formal accession negotiations with the EU - and with conditions attached.

Despite the fact that the start of accession talks has brought Turkey institutionally closer to the $\mathrm{EU}$, the optimistic mood among the Turks and the Europeans soon took a negative turn. Suspicions of Turkey's suitability for membership have grown ever since. ${ }^{45}$ European public opinion is wary of the presence of a Muslim community in the EU. If the question of Turkey's eventual accession were put to public referenda, overwhelming majorities in countries like Austria and France would likely cast negative votes. ${ }^{46}$

Recently, objections to Turkey's membership on the basis of identity-related considerations have increased, while arguments in favor of Turkish accession on the basis of cost-benefit calculations have lost ground. With the rise of Islamophobic sentiments across the European continent in the aftermath of the September 11 attacks, coupled with growing security concerns over the existence of approximately 20 million Muslims, the EU has increasingly become reluctant to develop a strong geopolitical commitment to Turkey's eventual accession. ${ }^{47}$

Worst of all, accession negotiations were suspended on eight of some 35 chapters, each of which must be successfully completed for full membership, only a year after the start of the process, because of Turkey's resistance to European requests to open its sea and air ports to Greek Cypriot naval vessels and airplanes. Against this background, it would not be unfounded to argue that prospects for Turkey's accession talks to be completed at an early date are not promising. They are likely to take a long time, due to a number of structural problems in the relations between Turkey and the EU..$^{48}$

\section{IRAN'S NUCLEAR PROGRAM}

Opinions in Turkey toward nuclear weapons in general and Iran's nuclear program in particular exhibit stark differences, depending on one's perspective. While, on the one hand, a significant degree of public support exists for Iran's nuclear endeavors, on the other hand, serious concerns about the possible negative implications of Iran's growing nuclear capabilities are also expressed by the security elite. The common denominator between the two sides seems to support the idea of Turkey's nuclearization.

\section{Public Perceptions}

There has not been a serious discussion, let alone a public debate, in Turkey about nuclear weapons for decades, even 
though U.S. nuclear weapons have been deployed in Turkey since 1960. One of the main reasons for this has been the ultimate authority of the military in matters relating to national security. Hence, partly because of the silence of the political and security elites and partly because of the lack of public interest in nuclear weapons, governments in Turkey have not experienced any difficulty in adopting policies regarding nuclear-weapons deployment on Turkish territory. In comparison to some other NATO countries such as Norway, which preferred to remain nuclear-weapons free, or Germany, where serious debates took place over the deployment of U.S. nuclear weapons on German soil, it would be fair to say that there was no discussion in Turkey. ${ }^{49}$

The disclosure of Iraq's clandestine WMD programs in 1991 was not enough to prompt a substantial public debate, either. This ought not to be the case for a country like Turkey, which sits in the immediate proximity of the Middle East, the most volatile region in the world, acknowledged as fertile soil for state WMD aspirations. However, today there is every reason for Turks to wonder and to discuss publicly whether their neighbors are attempting to develop WMD, their means of delivery having been acquired already, and what should be done to counter the threat. Revelations about Iran's clandestine enrichment program in August 2002 have finally brought the debate into the open, not only with its military-strategic implications, but also with its political implications for Turkey's domestic and foreign policies.

Iran's nuclear ambitions are mostly welcome among the Turks for a number of reasons. $^{50}$ First, Iran's defiance of U.S. pressure to halt its enrichment program is considered to be a dignified stance by a small country against a global hegemonic power. Second, Islam is a common denominator between the Turks and the Iranians, and the emergence of another Muslim nation — after Pakistan — with atomic power to deter the Christian and Jewish bombs is considered a necessary equalizer. Third, and in relation to the second, anti-American and anti-Israeli sentiments built up since the U.S. invasion of Iraq, are so intense that anything seen as hurting American or Israeli interests is usually welcome.

There are hundreds of Internet sites, blogs and chat rooms in which Turks exchange their views on whether Iran's nuclear ambitions constitute a threat to Turkey and whether Turkey should possess nuclear weapons. The majority of Turks do not believe that Iran, as a friendly Muslim nation, would want to threaten Turkey with its nuclear weapons, today or in the future, especially when Israel is considered Iran's prime target. The prevailing view among Turks supports the possession of nuclear weapons, for reasons similar to those expressed in the past by other countries. ${ }^{51}$

\section{Views Among the Security Elite}

Notwithstanding the above-mentioned sentiments in support of Iran's nuclear ambitions, which are quite pervasive in Turkish public opinion, intellectuals, journalists, community leaders, and retired civil and military bureaucrats have also assessed the negative implications of Iran's nuclear ambitions for Turkey's national interests. Gunduz Aktan, a retired ambassador and member of parliament from the Nationalist Movement party (Milliyetci Hareket Partisi, MHP), argued in March 2005: "Iran's being on the path to producing nuclear weapons is a secret everybody 
knows. ${ }^{" 52}$ After enumerating several cases wherein Iran deliberately acted to the detriment of Turkey, Aktan contended, "Attaining nuclear weapons will elevate Iran to the status of a regional power, which it does not deserve, considering its political regime and economic-development level." ${ }^{53}$ Turkey, to Aktan, does not want "a conflict in the region after its Iraq experience, but it does not want Iran becoming a nuclear power either." ${ }^{54}$

Prof. Umit Ozdag from Gazi University in Ankara, founder of the Eurasian Center for Strategic Studies (ASAM), stated in March 2005, "Iranian attainment of nuclear weapons would cause Iran to gain gravity in regional developments, in the Middle East, Central Asia and the Caucasus at the expense of Turkey. For example, a nuclear Iran will have more influence over Azerbaijan." ${ }^{55}$ To Ozdag, "Turkey will not accept living side by side with an Iran possessing nuclear weapons for a long period of time, and it will produce nuclear weapons to achieve balance, since it will be difficult to live with an Iran whose self-confidence has excessively mounted. Also, the ensuing shift in the power of conservatives in Iran will have adverse implications for Turkish-Iranian relations." ${ } 56$

In the wake of the Iranian elections in June 2005, Cuneyt Ulsever, liberal columnist in the daily Hurriyet, pointed to Mahmoud Ahmadinejad's declarations during the election process about his desire to develop nuclear power in Iran. According to Ulsever,

Turkey in its region and even in its borders is facing a neighbor whose worldview is in complete contradiction with its worldview, which claims preponderance in the region, which has an ingrained and strong state tradition, which is adept in issues of intelligence, counter-espionage and disinformation, which aims at possessing nuclear power, and which now explicitly states its intention to advance in this direction. ${ }^{57}$... Turkey cannot consider the remarks of a regime that pursues imperial policies in its region and gives priority to ideological acrimony, that renounces the production of nuclear weapons as a guarantee since the existence of nuclear power is the threat itself and there is no guarantee that a country openly cooperating with terrorists will not deliver nuclear power to its accomplices when it is in trouble. May God be with Turkey in the Ahmadinejad era. ${ }^{58}$

Dogan Heper, a columnist in the daily Milliyet argued in January 2006, "Following the end of the Cold War, the world has entered a process of turmoil or a process of restructuring. Even though, today, it is not possible to give a lucid answer to the question of how long this process will continue and what the shapes of the states will be, in order not to regret at the end of this process Turkey should take preventive measures, that is, it should be strong." For Heper, the first condition of being strong is "not to compromise the unity and the integrity of Turkey and to attach importance to nuclear research and development." Heper states three main reasons to bolster the argument that it is essential for Turkey to develop nuclear weapons. First, possessing nuclear weapons is a means to protect the unity and integrity of Turkey and its standing in the region. Second, in addition to buoying its standing in the region, an army possessing such a capability would render Turkey an arbiter, a determining power in its region. Third, a 
success in the nuclear arena would boost the morale of the Turkish people. This, in turn, would unite 70 million people and consolidate their pride in being Turkish citizens. For Heper, Turkey's elevation to the status of a nuclear power seems to be a somewhat inevitable outcome, because, he contends, "new conditions in the world are compelling Turkey to develop nuclear weapons." 59

Assoc. Prof. Celalettin Yavuz, Navy Captain (ret.), argued in February 2006, "Nuclear energy technology is an impetus for space research and for possessing nuclearweapons technology in order to contribute to Turkey's deterrence capability." 60

A former independent member of parliament from Istanbul, Emin Sirin, stated in May 2006 in a press conference under the roof of the Turkish Grand National Assembly, "There is no humor in this issue, and if Iran will not relinquish its ballistic missiles and nuclear weapons program, so as to preserve the regional balance, Turkey must necessarily obtain nuclear weapons and ballistic missiles and sustain the balance." 61 It is interesting to note the arguments of some top-ranking military officers, such as former Commanders of the Turkish Air Force, Gen. Halis Burhan (ret.) and Gen. Ergin Celasin (ret.): "If Iran develops nuclear weapons, Turkey should do the same so as to be able to preserve the balance of power between the two countries and also in the region."

Similarly, former Minister of State Vehbi Dincerler, from the right-of-center and conservative Motherland party (Anavatan Partisi, ANAP), takes the issue to yet another level: "Turkey should not only develop nuclear weapons, but the quantity as well as the quality of Turkey's nuclear weapons arsenal should be on a par with those of the other nations in the region," pointing at the Israeli nuclear capability. ${ }^{62}$ In the same vein, Col. Taner Altinok, Ph.D., director of the Institute for Defense Studies of the Turkish Military Academy in Ankara, argues, "Turkey should definitely follow the path that Iran walked over the years, both for energy generation purposes so as to meet Turkey's growing demand for energy and also for attaining a nuclear-weapons capability to better protect Turkey's national interests. Regional balances and conjectural developments compel Turkey to do so." ${ }^{63}$

\section{OTHER FACTORS}

It is possible to infer from the above statements that, with or without the incitement of Iran's nuclear program, Turkey may be on the way to seeking a nuclearweapons capability. However, as worrisome as it might be in theory, there is actually no need to press the panic button, provided that some steps are taken by the friends and allies of Turkey. Besides, it would not be advisable for Turkey to "go nuclear" under any circumstances.

Even though there is much talk in Turkey about why the state should develop nuclear weapons among those who approach the issue from the perspective of national pride and prestige as well as security, most decision makers are quite aware that the possible consequences of going nuclear would mean violation of Turkey's international obligations. Outside powers point to the difficulties Turkey may have to endure, but it also is state practice in institutions such as the Ministry of Foreign Affairs and the military. These entities have always formulated and conducted Turkey's foreign and security policies in line with Ataturk's dictum, 
"peace at home, peace in the world." Against this backdrop, one should not expect Turkey to embark upon a rushed nuclear weapons program, even if Iran crosses the critical threshold. Should this happen, however, what will keep Turkey from developing nuclear weapons will not simply be responsible state practice. The extent to which Turkey's allies are willing and able to allay its fears emanating from the worsening regional security situation will also have a decisive effect on policy makers. Improving relations with the United States and the EU, as well as strengthening the nuclear nonproliferation regime, will make the greatest impact in this regard.

\section{TURKISH-AMERICAN RELATIONS}

After the failure of the Turkish Parliament on March 1, 2003, to pass a resolution allowing the stationing of at least 60,000 American troops in Turkish territory, which was said to constitute the crux of the U.S. strategy in its war on Iraq, Turkey lost its significance in the eyes of the Bush administration. Despite sporadic and shortlived improvements in relations between the two countries, especially at times of high-level visits, the U.S. policy toward Iraq apparently assigns much greater weight to the demands of the Kurds in northern Iraq than those of its long-time NATO ally. This suggests that the general nature of bilateral relations may not be any better and may even be worse. An indication of this has been the unanticipated and much resented attitude of the U.S. leadership during Turkey's recent ground operation against the PKK strongholds in northern Iraq. Even though the White House and the Pentagon were provided detailed information in advance about the scope, purpose and scale of the operation, the undiplomatic statements made by Defense Secretary Gates and President Bush ("Turks should get out") have once again underlined the fact that the United States considers the Kurds in northern Iraq its primary strategic ally. ${ }^{64}$ If the newly elected President Barack Obama and his chief executives can look at world politics from a wider perspective and see how much Turkey fits into its strategic calculations, a level of strategic partnership may be mutually rewarding. Otherwise, decisionmakers of the next generation will be more likely to assign strategic value to the possession of nuclear weapons as powerful deterrents against threats to national security. ${ }^{65}$

\section{RELATIONS WITH THE EU}

The quantity and quality of reforms in Turkey have been unprecedented since the intensification of relations with the EU following the 1999 Helsinki summit decisions that formally declared Turkey a "candidate state" for eventual full membership. The impetus of candidacy has been enormous, especially in overcoming the deeply entrenched resistance in both the public domain and the civil and military bureaucracy to the reform packages that have been put in effect one after another. The legal, political, economic, social, cultural and institutional outlook of Turkey has been transformed dramatically. Nongovernmental organizations, interest groups and civilian activists flourished and soon gained substantial ground in the formulation of policies by concentrating their efforts in important issue areas with a view to putting Turkey on the right track and keeping it there.

Nevertheless, as noted earlier, the mood in Europe has become more negative 
with respect to the prospects for Turkey's eventual full membership. Suspension of the accession negotiations has exacerbated Turkish public resistance to the EU requests to take further steps toward democratization and economic growth. The net effect has been the weakening of the impact of civil-society organizations on the policies of the government, which had once relied heavily on their support to come to power and stay there through the 2002 and 2007 parliamentary elections.

The awareness of societies around the world of the perils of nuclear proliferation is increasing with the growth of mass media, where the consequences of WMD development are discussed publicly. This positive trend in some parts of the world notwithstanding, the feeble opposition to the nuclearization of Turkey cannot be compared to the degree of overwhelming support in the Turkish public domain given to nuclear projects and the value assigned to the acquiring of nuclear power. Hence, unless the batteries of the engine driving relations between Turkey and the EU (accession negotiations) can be recharged, there may be little hope that Turkey will abjure nuclear weapons for long.

\section{STRENGTHENING THE NONPROLIFERATION REGIMES}

North Korea acquired scientific and technological capabilities and then decided to walk away from the NPT in the run-up to its first nuclear detonation in October 2006. Iran, being a party to the NPT, has managed for many years to conceal its efforts to establish significant capabilities to enrich uranium and produce heavy water, both of which are important landmarks on the route to nuclear weapons development. Iraq and Libya had displayed similar efforts while staying in the NPT. These are unequivocal signs of the weaknesses inherent in the nuclear nonproliferation regime. A major achievement has been the conclusion of the Additional Protocol. It has surely strengthened the IAEA's safeguards regime, though it has yet to enter into force, especially in the states of concern, including Iran. However, even the experts argue that this is not enough. ${ }^{66}$

\section{WHY TURKEY SHOULD NOT GO NUCLEAR}

If improved relations can be achieved between Turkey and the United States as well as the EU, and the nuclear nonproliferation regime can be further strengthened, Turkey's acquisition of nuclear technology will not necessarily become a cause for serious concern. Turkey will be under the scrutiny of the international community through the effective implementation of IAEA safeguards as a state party to the NPT. This must be kept in mind, particularly by those in Turkey who might still aspire to nuclear-power status.

Another factor to remember is that virtually no state has developed nuclear weapons without substantial support and effective cover from a superpower or technologically advanced country. It is not just speculation that the United Kingdom and France received various degrees of scientific or technological support from the United States at various stages of their nuclear-weapons programs. Israel received support from France and Norway in overcoming scientific and technological barriers in the construction of the Dimona reactor, which is central to its "opaque" nuclear capacity. ${ }^{67}$ Similarly, South Africa benefited from its nuclear ties with foreign countries, particularly Israel, in building its 
nuclear weapons. ${ }^{68}$ On the other hand, Pakistan gained technology from many sources. This extensive assistance is reported to have included, among other things, uranium-enrichment technology from Europe and blueprints for a small nuclear weapon from China, along with missile technology. ${ }^{69}$ The Indian nuclearweapons program might not have been possible without the technology and material provided by Canada and the United States. ${ }^{70}$ China received partial support from the Soviet Union when their relationship was permissive, and China in turn provided support to the Pakistani and North Korean nuclear programs. In the case of Iran, the role of China and Russia cannot be overlooked.

Hence, one particular condition for Turkey to go nuclear would be to secure the endorsement of such a power. This, however, is not imminent. Short of such support, the only possible way of meeting the scientific and technological requirements would be through an illegal network similar to that of Abdel Qader Khan, the "father of the Pakistani bomb," now under house arrest in Pakistan. The magnitude and scope of illegal acquisition would be extremely difficult, if not impossible, in a country like Turkey, where there are still small but effective groups of concerned people who would do their best to reveal such critical information to the world. Should such a development take place, Turkey would be treated as a "rogue state,"something unthinkable and unacceptable given Turkey's record of nonproliferation efforts.

Notwithstanding these difficulties, even if one considers for a moment that Turkey has decided to go nuclear and managed to get the support of a nuclear power, or that it has established a clandestine nuclearweapons procurement network and gotten away with it without being noticed, what will be the role of nuclear weapons in Turkey's security and foreign policies? Will nuclear weapons enhance Turkey's security? Or, will they simply harm Turkey's interests?

The lead author of this article has spent years studying military history, superpower rivalry, arms control, disarmament and nonproliferation. Even when looked at from these rich perspectives, no feasible scenarios are imaginable under which nuclear weapons would bring additional security to Turkey. On the contrary, any attempt to illegally pursue, let alone acquire, nuclear weapons will be extremely damaging to Turkey's vital interests. Turkey is passing through a difficult domestic and international political conjuncture in which there are many sensitive issues (social, economic, political) to be exploited by its rivals. In addition, at a time when its relations with the United States and the EU are in decline, these countries may be of no help in dealing with the problems that will arise.

If one imagines for a moment that Turkey has acquired nuclear weapons capability, under which scenarios and against whom will these weapons have added value in Turkey's foreign and security policies? It is hard to give a meaningful answer to this question. Out of Turkey's neighbors, Iraq is under U.S. occupation and will be its protectorate possibly for a long period to come. Even if the United States withdrew fully from Iraq, its commitment to the security of that country will most likely remain the same. Syria, even with its ballistic missiles and chemical-weapons arsenal, could not deter 
Turkey's coercion in 1998, aimed at expelling the head of the PKK, Abdullah Ocalan, from that country. Even if Iran's nuclear-weapons capability disrupted its balance of power with Turkey, this alone might not be a justification for going nuclear, with all the hardships this would entail. A nuclear-weapons-capable Iran will most likely have to be dealt with collectively by the international community, the United States and Israel at the forefront. Greece and Armenia are other potential countries with which Turkey has had problems in its foreign relations. However, the EU membership of Greece and the powerful Armenian diasporas in the United States and Europe will most likely nullify the nuisance potential of a nuclear Turkey. In addition, Turkey has good neighborly relations with the rest of the countries in its environs, such as Bulgaria, Romania (now NATO allies), the Ukraine, Georgia and Russia (which still keeps a large nuclear arsenal). Thus, there seems to be no possible feasible scenario whereby Turkey could expect effective use of its nuclear power-status. However, there are scenarios in which Turkey's vital interests can be seriously damaged simply because it will have attempted, or even succeeded, in acquiring a nuclear-weapons capability.

It is unfortunate that a debate has taken place in Turkey for the last several years around this subject, without the contribution of informed and educated views from experts in the field. Most of the debate is emotional, reactive to daily events, and also partly ideological. These reactions, however, must be avoided in order to preserve Turkey's political unity and territorial integrity for as long as possible and to serve the primary interests of the Turkish nation. For this to happen, the factors that trigger such a debate must be eliminated, including, among others, the possibility of Iran's nuclear-weapons development. Second, intellectuals, community leaders and concerned citizens must get involved in the debate in order to enlighten the public as well as the decisionmakers. Third, Turkey must invest in the scientific and technological areas that will seize the future and help advance the quality of life in the country and in the rest of the world.

\footnotetext{
${ }^{1}$ Ronald Grigor Suny, "Provisional Stabilities: The Politics of Identities in Post-Soviet Eurasia," International Security, Vol. 24, No. 3, Winter 1999-2000, pp. 139-178.

${ }^{2}$ According to the U.S. Department of Energy, Iran supplied 14 percent of China's oil imports in 2003 and is expected to provide an even larger share in the future. China is also expected to rely on Iran for a large share of its liquid natural gas (LNG) imports. In October 2004, Iran signed a 25 -year contract worth $\$ 100$ billion with Sinopec, a major Chinese energy firm, for joint development of one of its major gas fields and the subsequent delivery of LNG to China. This deal will constitute one of China's biggest overseas investments and represent a major strategic linkage between the two countries. India is also keen to obtain oil and gas from Iran. In January 2005 the Gas Authority of India Ltd. (GAIL) signed a 30-year deal with the National Iranian Gas Export Corporation for the transfer of as much as 7.5 million tons of LNG to India per year. The $\$ 50$ billion deal will also entail Indian involvement in the development of Iranian gas fields (Michael T. Klare, Oil, Geopolitics, and the Coming War with Iran, April 11, 2005, at www.commondreams.org/views05/041121.htm.

${ }^{3}$ Iran's support to Hezbollah and Hamas (whose militants staged attacks on Israeli targets), its alleged role in the instability in Iraq and the Palestine problem are among the other serious bones of contention between Iran and the United States.
} 
${ }^{4}$ The oldest fixed boundary in the Middle East, the Turco-Persian border, was established in 1639 by the Treaty of Kasr-i Shirin, also called the Treaty of Zuhab (Maurice Harari, The Turco-Persian Boundary Question: A Case Study in Boundary Making in the Near and Middle East, Ph.D. Dissertation, (Columbia University, 1958).

${ }^{5}$ In a press conference in Washington, D.C., on August 14, 2002, the U.S. Representative Office of the National Council of Resistance of Iran revealed the top-secret nuclear projects of Iran, namely the uraniumenrichment facility in Natanz and the heavywater production facility in Arak.

${ }^{6}$ In 1990, on January 31, Prof. Muammer Aksoy, Ph.D., and on October 6, Assoc. Prof. Bahriye Ucok, two Kemalists, secular academics and intellectuals, were killed in their homes allegedly by secret service operatives of Iran. On January 24, 1993, renowned journalist and author Ugur Mumcu was assassinated with a bomb planted in his car. Mumcu had authored numerous pieces on Iran's activities against Turkey's secular system. Similarly, the assassination-by-car-bomb on October 21, 1999, of Prof. Ahmet Taner Kislali, Ph.D., a wellknown university professor and journalist devoted to secularism and Kemalism, one day after the arrest of 92 Hezbollah militants reportedly "trained in Iran," led to blistering attacks in the Turkish press that Tehran not only supported the PKK, but also the deadly Islamist Hezbollah, who, it was claimed, advocated and tried to establish an Islamist-Kurdish state in southeast Turkey throughout the 1990s. Just one day after Kislali's assassination, three Iranians were detained at the Istanbul Ataturk airport while trying, allegedly, to flee the country. See Robert Olson, "Turkey-Iran Relations, 1997 to 2000: The Kurdish and Islamist Questions," Third World Quarterly, Vol. 21, No. 5, pp. 871-890.

${ }^{7}$ Alvin. Z. Rubinstein and Oles M. Smolansky (eds.), Regional Power Rivalries in the New Eurasia-Russia, Turkey, and Iran (M.E. Sharpe, 1995).

${ }^{8}$ On February 1, 1997, a rally to protest Israel's occupation of East Jerusalem was held in Sincan with the participation of the local Turkish politicians and the Iranian ambassador. Placards supporting Hamas and Hezbollah were displayed. Many news agencies followed the event. See M. Hakan Yavuz, "Turkish-Israeli Relations through the Lens of the Turkish Identity Debate," Journal of Palestine Studies, 1997.

9 "Milliyet," Turkish Daily, February 5, 1997, at http://www.milliyet.com.tr/1997/02/05/siyaset/sincan.html. See also Ben Lombardi, “Turkey-The Return of the Reluctant Generals?” Political Science Quarterly, 1997. ${ }^{10}$ M. Hakan Yavuz, "Turkish-Israeli Relations through the Lens of the Turkish Identity Debate," Journal of Palestine Studies, 1997; Ben Lombardi, “Turkey-The Return of the Reluctant Generals?" Political Science Quarterly, 1997; Asli Aydintasbas, “The Malaise of Turkish Democracy," Middle East Report, 1998.

${ }^{11}$ Mehran Kamrava, "Military Professionalization and Civil-Military Relations in the Middle East," Political Science Quarterly, 2000.

${ }^{12}$ Chris Morris, “Turkey Bans Islamist Party," The Guardian, January 17, 1998, at www.guardian.co.uk/ turkey/story/0,,853796,00.html.

${ }^{13}$ Hootan Shambayati, “A Tale of Two Mayors,” International Journal of Middle East Studies, No. 36, 2004, pp. 253-275.

${ }^{14}$ Mustafa Kibaroglu, "Turkey Says No," The Bulletin of the Atomic Scientists, Vol. 59, No. 4, July/August 2003, pp. 22-25.

${ }^{15}$ Mustafa Kibaroglu, “Turkey and Israel Strategize,” Middle East Quarterly, Vol. 9, No. 1, Winter 2002, pp. 61-65.

${ }^{16}$ Mustafa Kibaroglu, Turkey Says No.

${ }^{17}$ Mustafa Kibaroglu, "Clash of Interest over Northern Iraq Drives Turkish Israel Alliance to a Crossroad," Middle East Journal, Vol. 52, No. 2, Spring 2005.

${ }^{18}$ Hikmet Erdogan, Büyük Israil Stratejisi [Grand Israeli Strategy], (Istanbul: IQ Kültür Sanat Yayinlar?, 2005). See also Prof. Cemal Anadol, Ph.D., Israil ve Siyonism Kiskacinda Türkiye [Israel and Turkey Knotted with Zionism], Second Edition, (Istanbul: Bilen Karinca, 2004).

${ }^{19}$ The so-called Ulusalci intellectuals belong mainly to the left-of-centre and anti-imperialist ideologies and they are, therefore, different from the right-of-center and conservative "nationalist" intellectuals. But, due to the above-cited incidents, both groups have converged on the "anti-Americanism" common denominator.

${ }^{20}$ The AKP formed a single-party government by obtaining 35 percent of the votes and 65 percent of the seats in the Grand National Assembly with the November 2002 elections. In the July 2007 elections, the AKP increased its votes to 47 percent and gained almost the same number of seats in the Parliament.

${ }^{21}$ Zerin Elci, “Hamas Delegation Visits Turkey, May Meet Erdogan,” Reuters, February 16, 2006. 


\begin{abstract}
${ }^{22}$ Mustafa Kibaroglu, "New Tests for Turkey's Evolving Security Relationship with Israel," Terrorism Focus, February 20, 2008, at http://jamestown.org/terrorism/news/article.php?articleid=2373981.

23 “'Gul'den Sonra Erdogan'dan da Iran'a Güvence [Assurances to Iran from Erdogan after Gul]," Milliyet, March 12, 2007.

${ }^{24}$ Prime Minister Erdogan made these remarks during a press conference after he participated in the annual
\end{abstract} Munich Security Conference in Munich, Germany, on February 9, 2008. The press conference was broadcast live on Turkish TV channels such as NTV and CNN Turk.

${ }^{25}$ Author's conversations over a long period of time, especially since 2002, with high-ranking military and diplomatic officials as well as academics and experts in Turkey, many of whom spoke on the condition of non-attribution. Of these, however, Mr. Seyfi Tashan, founder and director of the Foreign Policy Institute in Ankara (October 2007); former Commanders of the Turkish Air Force Gen. Ergin Celasin (ret.) and Gen. Halis Burhan (ret.) (February 2008); former Minister of State Vehbi Dincerler (February 2008); and Col. Taner Altinok, Ph.D., Director of the Institute of Defense Studies at the Turkish Military Academy in Ankara (March 2008) have granted the permission to be cited with their personal views on the subject matter that will be mentioned later in the text.

${ }^{26}$ The National Security Council (NSC), once a powerful institution that determined strict guidelines for governments as well as the entire state mechanism as to how to govern the country, has been transformed into a more Western-style advisory board on national security matters. The NSC meets regularly every two months, and whenever needed, with the participation of top representatives of the government, the armed forces, and other relevant departments of the state apparatus.

${ }^{27}$ Nuray Basaran, "Ozkk Pasa'dan Duydugum Ilk Mesajlar [First Messages that I Heard from General Ozk.k]," Aksam, April 22, 2005. For more on the official position of the Turkish Armed Forces, see www.tsk.mil.tr.

28 "Gül'den ABD Ziyareti Oncesi Iran Mesaji [Gül's Message about Iran before His Visit to the USA]," Evrensel, June 17, 2006.

${ }^{29}$ Adem Kadam, "Erdogan: Biz de Nükleer Enerji Icin Calisma Yapmaktayiz [Erdogan: We Too are Working for Nuclear Energy]," Milliyet, May 21, 2006, at http://www.milliyet.com.tr/2006/05/21/son/sonsiy07.asp.

${ }^{30}$ Turkey's rather late ratification of the NPT may raise the question of whether Turkish politicians wanted to keep the nuclear option open. Conventional wisdom does not suggest that this is likely. However, the traditional weight and, hence, the undisputed influence of the military and the decision-making process on matters relating to national security, was probably a factor that delayed ratification for some time. During the 1970s, when interest in nuclear (as well as other) weapons of mass destruction and their delivery means was growing in neighboring countries like Iran, Iraq, and Syria, the Turkish military elites might not have wanted to give an impression by means of a hasty ratification that Turkey would definitely forgo the nuclear option. Although they had no real intention in that respect, the Turkish elites might have wished to leave the issue ambiguous, as a deterrent to regional rivals and enemies. The other side of the coin should also be mentioned. In the second half of the 1970s, Turkey went through a period of chaos that prompted military intervention in 1980, which, according to many political analysts, rescued the country from the brink of an all-out civil war. Therefore, one should not be surprised if the Turkish Grand National Assembly did not prioritize the ratification of the NPT at a time when the country was struggling with anarchy and when there was no nonproliferation culture. In addition, the two small-scale nuclear research and training reactors were probably not considered by policy makers as compelling reasons for speeding up the ratification process or for concluding a safeguards agreement with the IAEA. Mustafa Kibaroglu, "Turkey," in Harald Müller (ed.), Europe and Nuclear Disarmament (European Interuniversity Press, 1998), pp. 161-193.

${ }^{31}$ The Nuclear Supplier Group has reproduced a set of guidelines that most of the suppliers of nuclear plants and materials agreed to in London on September 21, 1977. Therefore, this group is equally known as the London Club. This set of guidelines is also attached to communication addressed on January 11, 1978, to the director-general of the IAEA. These guidelines for nuclear transfer are also labeled as INFCIRC/254. The initial signatories of the guidelines were Belgium, Canada, Czechoslovakia, France, the former German Democratic Republic, the Federal Republic of Germany, Italy, Japan, the Netherlands, Poland, Sweden, Switzerland, the UK, the United States and the USSR.

${ }^{32}$ The Zangger Committee, named for its Swiss chair, Prof. Claude Zangger, and the Nuclear Suppliers Group share the purpose of limiting the transfer of significant material and technology to states that are suspected of 
engaging in clandestine nuclear weapons manufacturing.

${ }^{33}$ The Missile Technology Control Regime is an informal, non-treaty association of states that have an established policy or interest in limiting the spread of missiles and missile technology. According to the guidelines, the MTCR's original purpose was to "reduce the risks of nuclear proliferation by placing controls on equipment and technology transfers which contribute unmanned nuclear weapons delivery vehicles." The MTCR puts limitations on the member countries' export of missiles with a range of $300 \mathrm{~km}$ and a payload of $500 \mathrm{~kg}$.

${ }^{34}$ For a comprehensive discussion on Turkey's efforts over the last four decades to develop a peaceful nuclear program, see Mustafa Kibaroglu, "Turkey's Quest for Peaceful Nuclear Power," The Nonproliferation Review, Vol. 4, No. 3, Spring/Summer 1997, pp. 33-44.

${ }^{35}$ Effective inspections carried out in Iraq under UN Security Council Resolution 687 have led to debate concerning whether the broad, but previously unexercised rights of the IAEA under basic NPT safeguards agreements could be used to carry out inspections beyond the routine inspections directed toward known declared activities. The Secretariat of the IAEA, after examining this issue, concluded that this right had existed all along, and, in February 1992, the Board of Governors agreed with this finding. Following this line of thought, throughout the 1990s, the IAEA has focused extensively on measures to make the safeguards system more effective and efficient. The major effort in this undertaking is "Programme 93+2," the IAEA's program to develop and test a comprehensive set of measures to improve safeguards implementation. The formal title of the program is "Strengthening the Effectiveness and Improving the Efficiency of the Safeguards System." The program formally began with the IAEA Board of Governors' endorsement of the proposed effort in December 1993 and concluded in December 1995. In this respect, see Mustafa Kibaroglu, "Turkey's Sweet \& Sour Policy Against WMD Proliferation," Turkish Policy Quarterly, Vol. 3, No. 2, Summer 2004, pp. 101-111. The document of ratification was published in the Official Gazette on July 16, 2001 in its 24,460 issue.

${ }^{36}$ Mustafa Kibaroglu, Turkey's Quest for Peaceful Nuclear Power.

${ }^{37}$ Mustafa Kibaroglu, "Turkey."

${ }^{38}$ Hans M. Kristensen, U.S. Nuclear Weapons in Europe: A Review of Post-Cold War Policy, Force Levels, and War Planning (Natural Resources Defense Council, February 2005), p. 9.

${ }^{39}$ Mustafa Kibaroglu, Turkey's Quest for Peaceful Nuclear Power.

${ }^{40}$ Mustafa Kibaroglu, "Iran's Nuclear Program May Trigger the Young Turks to Think Nuclear," Carnegie Endowment for International Peace, available on www.ceip.org.

${ }^{41}$ Mustafa Kibaroglu, "The Generals' Discontent," The Bulletin of the Atomic Scientists, Vol. 57, No. 2 March/ April 2001, pp. 28-30.

${ }^{42}$ Nearly 80 percent of Turkish people think that Turkey and the United States are not allies anymore. The findings of one such poll can be found at http://www.transatlantictrends.org.

${ }^{43}$ General Tuncer Kilinc (ret.), former secretary-general of the then-powerful National Security Council (MGK), was on record in March 2002, while he was still in office, for suggesting, among other things, forming an alliance with Russia, Iran and China.

${ }^{44}$ Deputy Chief of Turkish General Staff Gen. Ergin Saygun made explicit remarks about the degree of resentment among the Turkish military toward some of the allied countries for lack of cooperation in the fight against the PKK, during a symposium convened by the Center for Strategic Research of the Turkish General Staff (SAREM) on the subject matter, in Ankara on December 11, 2007. Similar remarks were reiterated by Commander of the Turkish Armed Forces Gen. Yasar Buyukanit during a symposium on "Global Terrorism and International Cooperation," convened by the NATO Centre of Excellence Defence against Terrorism (COE-DAT), in Ankara on March 10, 2008.

${ }^{45}$ See Tarik Oguzlu and Mustafa Kibaroglu, "Incompatibilities in Turkish and European Security Cultures Diminish Turkey's Prospects for EU Membership,” Middle Eastern Studies, Vol. 44, No. 6, November 2008, pp. 945-962.

${ }^{46}$ Antonio M. Ruiz-Jimenez, "European Public Opinion and Turkey's Accession: Making Sense of Arguments For and Against," European Policy Institute Network, Working Paper No. 16, 2007.

${ }^{47}$ Lauren M. McLaren, "Explaining Opposition to Turkish Membership of the EU," European Union Politics, Vol. 8, No. 2, 2007, pp. 251-278.

${ }^{48}$ Tarik Oguzlu and Mustafa Kibaroglu "Incompatibilities in Turkish and European Security Cultures 
Diminish Turkey's Prospects for EU Membership," Middle Eastern Studies, Routledge, Taylor \& Francis Group, forthcoming.

${ }^{49}$ During the period of short-lived and limited public interest in the deployment of the U.S. Jupiter missiles, the Cuban missile crisis of October 1962, and the developments that followed, nuclear issues were only sporadically and superficially debated in the public domain. Even then, the discussion focused on the domestic political repercussions of these issues, without touching their substance. Mustafa Kibaroglu, Turkey's Quest for Peaceful Nuclear Power.

${ }^{50}$ A quick scan of the Turkish media in any time interval can provide ample sources supporting the argument stated in this paragraph. Moreover, public opinion polls conducted by distinguished research centers such as the Pew Charitable Trusts also support the view that Iran is not considered by most Turks as an enemy of, or a threat to, Turkey (see http://pewglobal.org/reports/display.php?PageID=826).

${ }^{51}$ See www.zamansiz.com/turkiye-nukleer-silah-sahibi-olmali-mi; www.byturks.net/turkiye-nukleer-gucsahibi-olmali-mi; www.hackhell.com/archive; www.turkish-media.com/forum; and www.heavymetaltr.com.

${ }^{52}$ Gündüz Aktan, "Bolgenin Istikrari,” [Stability of the Region], Radikal, March 22, 2005.

53 Ibid.

54 Ibid.

${ }^{55}$ Umit Ozdag, "Iran Nukleer Silah Sahibi Olmali Mi?” [Should Iran Possess Nuclear Weapons], Aksam, March 7, 2005.

56 Ibid.

${ }^{57}$ Cuneyt Ulsever, "Dibimizdeki Nukleer Tehlike: Mahmud Ahmedinecad," [Mahmoud Ahmadinejad: Nuclear Threat in Our Vicinity], Hurriyet, June 27, 2005.

58 Ibid.

${ }^{59}$ Dogan Heper, “Türkiye 'Atom' Yapabilir,” [Turkey May Build Atomic Bomb], Milliyet, January $26,2006$.

${ }^{60}$ Celalettin Yavuz, “Turkiye Jeopolitiginin Oncelikleri ve Gereken Stratejiler [Priorities of Turkey's Geopolitics and the Required Strategies]," Türk Yurdu, Vol. 26, No. 222, February 2006.

${ }^{61}$ See http://www.tbmm.gov.tr/develop/owa/web_basin_aciklamalari.aciklama?p1=34274.

${ }^{62}$ Interviews with Gen. Burhan, Gen. Celasin and Mr. Dincerler, February 11, 2008 (Ankara).

${ }^{63}$ Interview with Col. Altinok, March 10, 2008 (Ankara). Similar views have been frequently expressed to the author by others from similar backgrounds whose names, however, cannot be cited here, as they spoke on the condition of anonymity, or no explicit permission has been asked by, or granted to, the author.

${ }^{64}$ Mustafa Kibaroglu, "Iraq's Next Five Years from the Perspective of Turkey," Bitterlemons.org, March 27, 2008 .

${ }^{65}$ Mustafa Kibaroglu and Tarik Oguzlu, "Turkey and the United States in the Twenty-first Century: Friends or Foes?" Korean Journal of Defense Analysis, Vol. 20, No. 4, Winter 2008, pp. 357-372.

${ }^{66}$ Author's conversations with Lawrence Scheinman and Lewis Dunn (Milano, Italy), March 13, 2008.

${ }^{67}$ Avner Cohen, Israel and the Bomb (Columbia University Press, 1998), p. 32.

${ }^{68}$ Jeffery Richelson (ed.), U.S. Intelligence and the South African Bomb, The National Security Archive, March 13, 2006, available at http://www.gwu.edu/ nsarchiv/NSAEBB/NSAEBB181/index.htm.

${ }^{69}$ Paul Kerr and Mary Beth Nikitin, Pakistan's Nuclear Weapons: Proliferation and Security Issues, Congressional Research Services, January 14, 2008, p. 2.

${ }^{70}$ George Perkovich, India's Nuclear Bomb: Impact on Global Proliferation (University of California Press, 1999). 